\title{
Lynxacarus radovskyi (Acari: Listrophoridae) in a domestic cat from Espírito Santo, Brazil*
}

\section{Lynxacarus radovskyi (Acari: Listrophoridae) em gato doméstico no Espírito Santo, Brasil}

\author{
Diana Menezes Santos Neves Aguirre, ${ }^{* *}$ Fabio Ribeiro Braga, ${ }^{* *, 1}$ Carolina Magri Ferraz, ${ }^{* *}$ Fernanda Toledo de Vieira, ${ }^{* *}$ \\ Felipe Boniedj Ventura Álvares, ${ }^{* * *}$ Samilla Alves Sobral, ${ }^{* *}$ Ricardo Leandro Oliveira Souza, ${ }^{* *}$ Vinicius Longo Ribeiro Vilela ${ }^{* *, 2}$
}

\begin{abstract}
Lynxacarus radovskyi is of uncommon occurrence and there are few reports in the state of Espírito Santo, Southeastern Brazil. The purpose of the present note is to record the occurrence of $L$. radovskyi in a Persian domestic cat in Vila Velha, Espírito Santo, Brazil. The animal was asymptomatic, without evidence of dermatological signs. The present report can be informative, once the lack of knowledge in relation to the ectoparasite presence and potential of spread in the regional cat population is constant in the veterinary medicine practice, may cause underreporting of infestations.
\end{abstract}

Keywords: ectoparasite, Listrophoridae, domestic cat, itching.

\section{Resumo}

Lynxacarus radovskyi é de ocorrência incomum e existem poucos relatos no estado do Espírito Santo, Sudeste do Brasil. O objetivo do presente relato foi reportar a ocorrência de L. radovskyi em felino doméstico da raça Persa em Vila Velha, Espírito Santo, Brasil. O animal apresentava-se assintomático à infestação, sem evidências de alterações dermatológicas. Este relato pode ser informativo, uma vez que a falta de conhecimento em relação à presença e potencial disseminativo deste ectoparasito é constante na prática da Medicina Veterinária, podendo causar subnotificações das infestações.

Palavras-chave: ectoparasito, gato doméstico, Listrophoridae, prurido.

In Brazil, according to IBGE (2015), there are approximately 22 million domestic cats, nearly 1.9 cats per household. In addition, regarding the presence of cats, $17.7 \%$ of households have at least one, the equivalent of 11.5 million households. However, in these animals the occurrence of ectoparasites can be frequent. Among the known ectoparasites belonging to cats, Lynxacarus radovskyi was only recently recognized and has had its occurrence increasingly reported (Romeiro et al., 2007; Aguiar et al., 2009). It is a sarcoptiforme mite, of the Listrophoridae family, small, usually adhered to the distal third of the fur shaft and can be visualized by bare eyes and most of the cases are asymptomatic, but severe infestations may occur with alopecia, pruritus, excoriation lesions, desquamation and miliary dermatitis (Campos et al., 2020).

Lynxacarus radovskyi is the etiologic agent of lynxacariosis, an uncommon disease that affects cats, especially in tropical regions, but there are also records in subtropical regions (Jayanthy et al., 2017). This disease is rarely evidenced in cats in the state of Espírito Santo, Southeastern Brazil, which was first reported in a Persian and exotic breed cats from a cattery (Maio et al., 2004). After that, another report only occurred in 2019, in a cat with association between infestation by L. radovskyi (Acari:
Lystrophoridae) and feline eosinophilic granuloma complex (Rocha et al., 2019)

The parasite can remain throughout its whole life adhered to the host's fur, where it is assumed that their nourishment comes from the surface of the fur, which probably makes most of cases asymptomatic (Han et al., 2019). The purpose of the present paper is to report the infestation of $L$. radovskyi in an asymptomatic Persian cat in the city of Vila Velha, Espírito Santo, Brazil. Fur sample was collected from a male, non-castrated, one year old, Persian race feline, for evaluation in a veterinary medicine class of the Universidade Vila Velha in Espirito Santo, Brazil. Apparently, the fur was normal, but presence of "filth" was noted.

Following, the fur was avulsed and conditioned in $10 \mathrm{~mL}$ test tubes containing $2 \mathrm{~mL}$ of $70 \%$ ethyl alcohol, sealed, identified, and transported immediately to the Laboratório de Parasitologia Experimental e Controle Biológico, Universidade Vila Velha-UVV. The specimens were placed on a microscope slide, adding two to three drops of $10 \%$ potassium hydroxide (Baker, 1968) after waiting for 10 minutes, a coverslip was placed and the specimens were examined under a light microscope, 100x magnification. The morphological characteristics were observed according to Faccini \& Coutinho (1986).

\footnotetext{
${ }^{*}$ Recebido em 2 de setembro de 2020 e aceito em 16 de junho de 2021.

**Laboratório de Parasitologia Experimental e Controle Biológico, Universidade Vila Velha-UVV, Vila Velha, ES, Brazil. ${ }^{1}$ Scholarship CNPq.

***Laboratório de Parasitologia Veterinária, Instituto Federal da Paraíba-IFPB, Sousa, PB, Brazil. ${ }^{2}$ Correspondence: (55) 83999073634 - email: vinicius. vilela@ifpb.edu.br, Zip code: 58807-630, Sousa, Paraíba, Brazil.
} 
After gathering and viewing the collected material (fur) at optical microscope, 40x objective, the presence of mites (Figure 1) was observed. Next, the presence of $L$. radovskyi was confirmed using the description of their morphology $(0.5 \mathrm{~mm}, 430$ to 515 $\mu \mathrm{c}$ in length; paws with terminal suction cups; and fast-moving) (Merchant, 1993). The most common clinical manifestations observed in cats affected by L. radovskyi are slight pruritus, fur with the appearance of sprinkled "salt and pepper" due to visibility of the mites and flaking (Jayanthy et al., 2017). In the present report, the animal was not attended in the veterinary medicine clinic sector because it did not show any clinical signs that corroborate with the presence of ectoparasites, nor any skin disease, being an "in class finding".

In the visualization of the fur sample, the sprinkled "salt and pepper" pattern was described (Rocha et al., 2019), however the animal had no clinical manifestation. Moreover, literature reports that in cats affected by $L$. radovskyi alopecia may occur due to easy fur withdrawal, excessive presence of dandruff and miliary dermatitis (Greve \& Gerrish, 1981). In the present study there was no evidence of any dermatological alterations. However, to avoid an increase in infestation, Fipronil spray (Frontline spray®, Merial Saúde Animal, Campinas, SP.) was administered in the parasitized areas, with repetition after one month. Subsequently, parasites were no longer observed in the animal, and the treatment was effective, similar to that observed by Aguiar et al. (2009).

Lynxacarus radovskyi usually affects cats (Romeiro et al., 2007; Aguiar et al., 2009), therefore the importance of this description is associated to the very few reports of its occurrence, in the state of Espírito Santo, with only one report in 2004. Thus, the lack of knowledge in relation to the presence and potential spread of this ectoparasite in the regional domestic cat population is constant in the veterinary medicine practice and, can guide this study as one more educational and research tool.
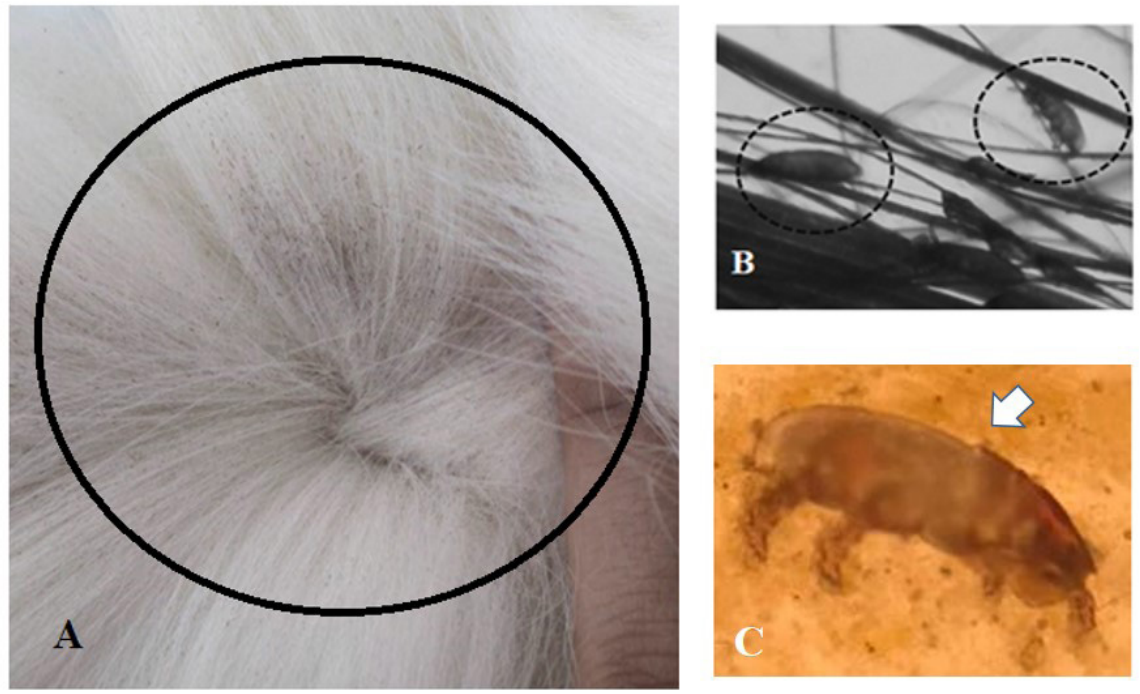

Figure 1: A: Fur (white) belonging to a domestic cat naturally infested by Lynxacarus radovskyi. B: parasites (circles) in 200x magnification. C: Parasite (arrow) in 400x magnification.

\section{Bioethics and Biossecurity Committee Approval}

This study was submitted to and approved by the Ethics Committee on the Use of Animals (CEUA-Universidade Vila Velha, Process Nº 306).

\section{Acknowledgements}

We want to acknowledge the Conselho Nacional de Desenvolvimento Científico e Tecnológico (CNPq), Fundação de Amparo à Pesquisa e Inovação do Espírito Santo (FAPES) and Coordenação de Aperfeiçoamento de Pessoal de Nível Superior (CAPES).

\section{Conflict of interest}

The authors declare no conflict of interest.

\section{References}

AGUIAR, J.; MACHADO, M.L.S.; FERREIRA, R.R.; HUNNING, P.S.; MUSCHNER, A.C.; RAMOS, R.Z. Infestação mista por Lynxacarus radovskyi e Felicola subrostratus em um gato na região de Porto Alegre, RS, Brasil. Acta Scient. Vet. v. 37, 301 305, 2009.
BAKER K.P. Observations on demodectic mange in dogs. J. Small Anim. Pract. 9, 621-625. 1986.

CAMPOS, D.R.; CHAVES, J.K.O.; ASSIS, R.C.P.; FERNANDES, J.I. \& SCOTT F.B. Efficacy of oral sarolaner against Lynxacarus radovskyi in naturally infested cats. Vet. Dermatol. 2020. doi:10.1111/vde.12857 
FACCINI, J.L.H. \& COUTINHO, V. Ocorrência de Lynxacarus radovskyi (Acari: Listrophoridae) em gatos domésticos no Brasil. Arq. Univers. Fed. Rural Rio Jan. v. 9, p. 91-93. 1986.

GREVE, J.H. \& GERRISH, R.R. Fur mites (Lynxacarus) from cats in Florida. Feline Pract. v. 11, n. 6, p. 28-30. 1981.

HAN, H.S.; CHUA, H.L. \& NELLINATHAN, G. Self-induced, noninflammatory alopecia associated with infestation with Lynxacarus radovskyi: a series of 11 cats. Vet. Dermatol. v. 30, 356-e103. 2019. doi:10.1111/vde.12749

IBGE- Instituto Brasileiro de Geografia e Estatística. Pesquisa Nacional de Saúde: 2013. Acesso e utilização dos serviços de saúde, acidentes e violências, Brasil, grandes regiões e unidades da federação, coordenação de trabalho e rendimento - Rio de Janeiro: IBGE 2015, 100pp.

JAYANTHY, C.; NAGARAJAN, B. \& LATHA B.R. Cat fur mite Lynxacarus radovskyi in India. J. Parasit. Dis. v. 41, n. 4, p. 1102-1104. 2017. doi:10.1007/s12639-017-0942-2
MAIO, F.G.; RAMALHO, F.D.; ARANTES, J.S.; ARANTES, M.Q. \& GIORDANI M.L. Ocorrência de Lynxacarus radovskyi (Acari: Listrophoridae) em gato doméstico nas cidades de Guarapari e Vila Velha, estado do Espírito Santo, Brasil. Rev. Bras. Parasitol. Vet. v. 13, p. 323. 2004.

MERCHANT, S.R. 1993. The Skin: Parasitic Diseases. In: Norsworthy GD. Feline Pract. p.515-516.

ROCHA, C.M.; FARIAS, P.C.G.; GORZA, L.; SOARES, F.E.F.; FERRAZ, C.M.; SOUZA, R.L.O.; RENON, L.B.S. \& BRAGA, F.R. Association between infestation by Lynxacarus radovskyi (Acari: Lystrophoridae) and the occurrence of Feline Eosinophilic Granuloma Complex. J. Parasit. Dis. v. 43, n. 4, p. 726-729.

ROMEIRO, E.T.; ALVES, L.C.; SOARES, Y.M.V.; MATOSO, U.N.V.; FAUSTINO, M.A.G. Infestação por Lynxacarus radovskyi (Tenorio, 1974) em gatos domésticos procedentes da região metropolitana do Recife, Pernambuco, Brasil. Rev. Bras.

Parasitol. Vet. v. 16, 159-162, 2007. 